\title{
UNIVERSITYOF
}

FORWARD

THINKING

WESTMINSTER用

WestminsterResearch

http://www.westminster.ac.uk/westminsterresearch

(I) as a sociolinguistic variable in Francoprovençal

Kasstan, J. and Müller, D.

This is a copy of the final version of an article published in the International Journal of the Sociology of Language, 249, pp. 99-118.

It is available from the publisher at:

https://dx.doi.org/10.1515/ijsl-2017-0039

The WestminsterResearch online digital archive at the University of Westminster aims to make the research output of the University available to a wider audience. Copyright and Moral Rights remain with the authors and/or copyright owners.

Whilst further distribution of specific materials from within this archive is forbidden, you may freely distribute the URL of WestminsterResearch: ((http://westminsterresearch.wmin.ac.uk/)).

In case of abuse or copyright appearing without permission e-mail repository@westminster.ac.uk 


\title{
Jonathan Kasstan* and Daniela Müller
}

\section{(l) as a sociolinguistic variable in Francoprovençal}

\author{
https://doi.org/10.1515/ijsl-2017-0039
}

\begin{abstract}
This article argues for (l) as a sociolinguistic variable in Francoprovençal: (l) refers to variable palatalisation of /l/ in obstruent + lateral onset clusters (/kl, gl, $\mathrm{pl}, \mathrm{bl}, \mathrm{fl} /$ ), a feature that has long been the subject of metalinguistic commentary, but no systematic analysis. Our data, which come from a larger study of Francoprovençal (FP), show significant intraspeaker variation. Sociolinguistic interviews were carried out in the Lyonnais region of France among 21 FP speakers with different acquisition routes. /1/-palatalisation is far from categorical in our sample, with increased rates of the French variant [1] over the traditional [j] variant. We interpret these data as contact-induced change: phonological leveling is underway, with convergence towards French. These findings are consistent with the language death literature, and are now widely reported in the context of other minority varieties spoken in the Hexagon. Conversely, some new speakers show different patterns with a greater range of palatalised variants. These findings add to a growing body of evidence that suggest laterals to be a locus for socio-indexical cues crosslinguistically.
\end{abstract}

Keywords: Francoprovençal, variation and change, language obsolescence, palatalisation, new speakers

\section{Introduction}

For some time now France's regional minority languages have been losing ground to French, which remains the only official language of the state. Today, most linguistic commentators would agree that these languages are at best vulnerable, and at worst obsolescent, with very few, if any, remaining monolingual speakers. In most cases this situation has resulted from gradual language shift rather than maintenance of stable diglossia. Campbell and Muntzel suggest that a long-term shift can lead to what they term "gradual death"

\footnotetext{
*Corresponding author: Jonathan Kasstan, Queen Mary University of London, London E1 4NS, UK, E-mail: j.kasstan@qmul.ac.uk

Daniela Müller, Ludwig-Maximilians-Universität München, 80539 München, Germany, E-mail: daniela.mueller@phonetik.uni-muenchen.de
} 
(1989: 184-185), defined as the process in which a minority language is lost in a long-term contact situation with a dominant language. This process is characterised by the levelling of highly localised linguistic features, intermediate stages of bilingualism, and an identifiable proficiency continuum of speakers (Dorian 1981). However, while these outcomes might occur in an unstable contact situation between dominant and minority languages, in environments with language planning strategies favouring revival and revitalisation, and where so-called new speakers emerge, language change of quite a different kind is also possible. These adult learners, "with little or no home exposure to a minority language but who instead acquire it through [...] education programs [or] revitalization projects (O’Rourke et al. 2015: 1), have been documented cross-linguistically as exhibiting common characteristics. For example, new speakers are now well-documented in the context of Breton. While traditional speaker numbers have been dwindling for some time, attempts to revitalise the traditional dialects have led to the development of a learner variety - néo-Breton - which is only reified by new speakers. These so-called néo-Bretonnants (Jones 1995) are characteristically middle-class, urban-dwelling, well-educated and highly politicised. In contrast to native speakers, new speakers typically acquire the minority variety as an academic exercise in an educational setting. As a result they speak a standardised, pan-regional variety of Breton, which in some cases is reported to be incomprehensible to native speakers (Jones 1998). The level of linguistic insecurity felt by these types of speaker can therefore be acute when contact between the two occurs (see Kasstan 2017).

The phenomenon of the new speaker as an emerging and important social actor in the continuum of speaker proficiency is of central interest to this article, which examines the changing sociolinguistic context of obsolescent Francoprovençal (FP). ${ }^{1}$ In presenting results from sociolinguistic interviews conducted in 2012, and comparing these data with historical evidence from the Atlas linguistique de la France (Gilliéron and Edmont 1902-1910) (ALF) and the Atlas linguistique et ethnographique du Lyonnais (Gardette 1950-1956) (ALLy), this article will argue that localised traditional forms are undergoing phonological levelling in the direction of Standard French (SF). Conversely, while emerging new speakers of FP broadly show the same patterns in casual speech, they

1 Unlike Breton, FP's status as a clearly demarcated linguistic system is long contested, with some viewing FP instead as a transitional zone between Oil French and Occitan (see Kasstan and Nagy, this issue). However, given its high degree of internal variability, it seems appropriate to view FP as a group of varieties with common features. 
can in some contexts produce variants that convey social work. In Section 7, we invoke the notion of indexicality (Silverstein 2003) to link the selection of such variants on the one hand with the sociolinguistic salience of the dependent variable, and, on the other, with affiliation to a new-speaker revitalisation movement in the wider region.

We begin with an overview of studies that have explored the sociolinguistic salience attached to laterals, before discussing /1/-palatalisation in FP. Thereafter we characterise FP in the Lyonnais area. Following an introduction to this region, and the methodology operationalised to collect and analyse the data, we discuss the findings and suggest avenues for further research.

\section{Laterals as a sociolinguistic variable}

Sub-phonemic variation of lateral consonants has been found to be a locus for socio-indexical cues in several languages, but few studies have systematically investigated the phenomenon. The most thorough of these is Christen's (1988) investigation of the Western Swiss German dialect spoken in the city of Lucerne and in the neighbouring countryside. In Western Swiss German, the lateral, especially in pre-consonantal and word-final position, is generally dark and even vocalised in many rural varieties. In her study of the socioindexical meanings of this variant in Lucerne and the small village of Knutwil, situated 25 kilometres from Lucerne, Christen (1988) was able to show negative judgments connected with the vocalised lateral for the urban population, whereas positive values were attached to this variant by the rural villagedwellers. This evaluation hinged on the evaluation of country life itself whether it was seen as desirable or backward. Within the village community, however, Christen (1988: 158) showed that wives evaluated the non-vocalised lateral as more prestigious. She also showed that female participants produced fewer vocalised variants than their respective husbands - craftsmen and farmers - who attached values of rural identity to their vocalised laterals and used them pervasively in almost all social settings. As attitudes toward dialects evolved positively in Switzerland from the end of the 1980s, the use of vocalised variants of / $1 /$ spread into dialectal regions which historically never had them (Christen 2001: 24). Christen thus interprets /1/-vocalisation as a sociophonetic cue which indexes local identity and speaker authenticity. More recently, Leeman et al. have shown that /1/-vocalisation has spread southward to major urban centres like Bern from the rural hinterlands; age appears to be a significant factor in these findings, with older speakers tending to vocalise 
more than younger speakers (2014: 214). The lateral as a socio-indexical carrier has also been discussed in the context of Catalan and Spanish in Catalonia (Simonet 2010); Polish in the first half of the twentieth century, when the dark lateral was still in the process of vocalising towards /w/ (Straka 1942); some varieties of American English, as well as Bristol English, where the use of an intrusive /1/ is "extremely socially marked" (Gick 2002: 175). ${ }^{2}$

The sociolinguistic observation most relevant to the situation described in the present article, however, is an anecdote from 16th-century Paris. In 1578, the grammarian Henri Estienne noted that men and women of the Royal Court took to pronouncing $/ \mathrm{pl} /$ clusters as [pj] in order to imitate a then fashionable Italian feature, due perhaps to the influence of the Queen Mother (see Jänicke 1997: 84-89). This short fad attests to the salience of palatalised /1/ and shows that speakers use it to convey social attributes and identity, such as aspirations of upward social mobility and prestige. While this is anecdotal evidence of the social-indexical nature of /1/-palatalisation, no quantitative production or perception studies have examined this feature in FP. This is despite the fact that /1/-palatalisation in FP has long been the subject of metalinguistic commentary: "Le fait le plus largement répandu, et sous les aspects les plus divers et les plus curieux, dans nos parlers, est la palatalisation de $\mathrm{L}$ dans deux catégories de groups combinés: vélaire $+\mathrm{L}$, labiale + L" [In our dialects, the most widespread feature, under the most diverse and curious of aspects, is the palatalisation of $\mathrm{L}$ in the velar $+\mathrm{L}$ and labial + L groups] (Duraffour 1932: 238).

\section{FP in the Lyonnais area}

While FP (in one form or another) was once a common language spoken across the Lyonnais region, today it is found in but a few isolated pockets in the westerly mountainous region of les monts du Lyonnais, and to the East in communes bordering the Dauphiné (on vitality, see Zulato et al., this issue). These western and eastern areas, which lie no more than 40 kilometres from the centre of Lyon, are accessible via public transport. Our fieldwork sites included the communes of Rontalon, Saint-Martin-en-Haut, and Saint-

2 In spite of this large body of evidence, we highlight that counterexamples can be found to the trend that /1/-vocalisation is socio-indexically salient. Studies of Australian and New Zealand English have found little statistical distinction of /1/-vocalisation by e.g. sex, social class (Horvath and Horvath 2002: 325). 
Symphorien-sur-Coise, ${ }^{3}$ which form a cluster of isolated rural communes in les monts du Lyonnais. The city of Lyon also formed part of the sample universe. Figure 1 illustrates our fieldwork sites (red) relative to those explored for the ALLy and ALF (blue).

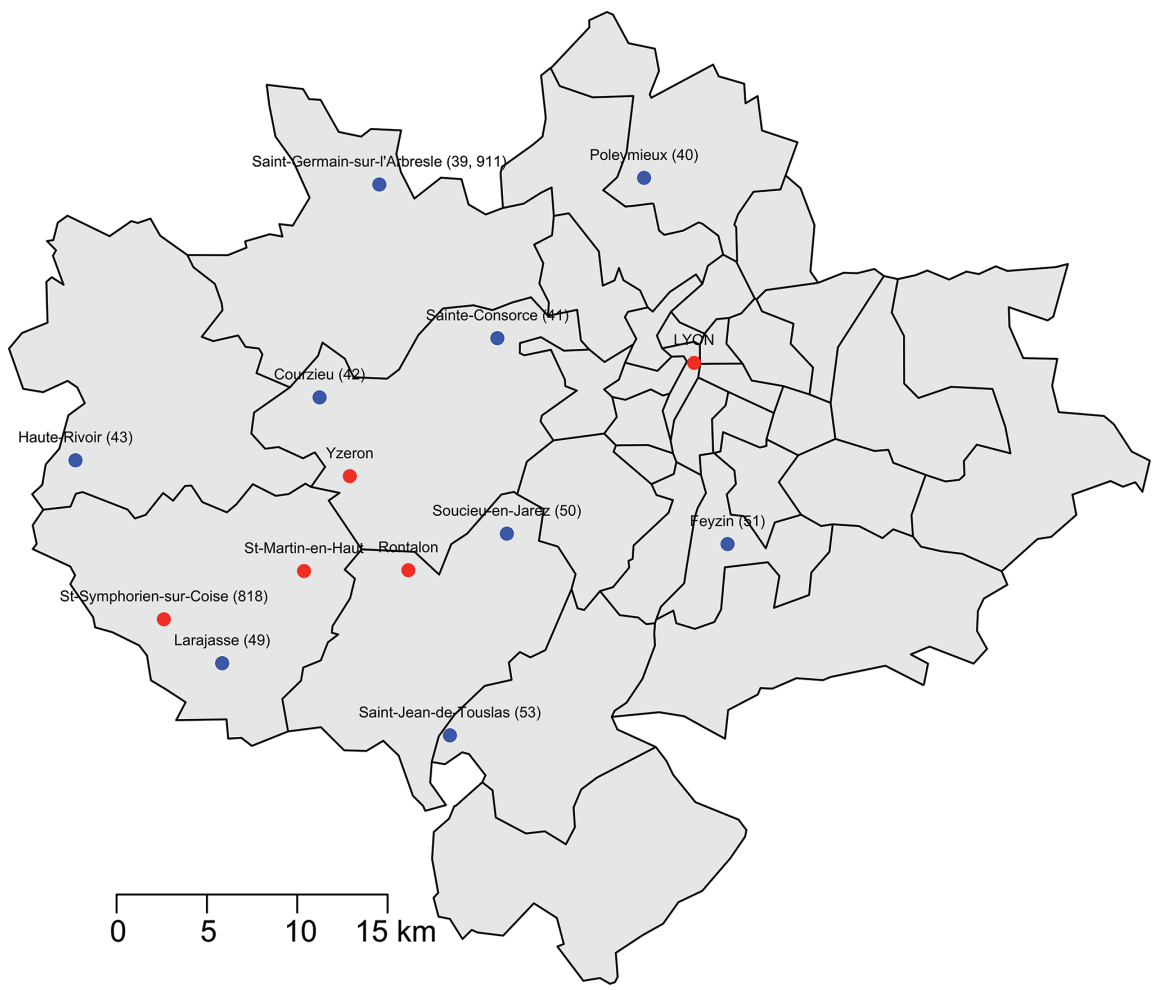

Figure 1: Department of the Rhône: fieldwork sites relative to ALLy and ALF data points).

\section{4 /l/-palatalisation in FP}

Lateral approximants in FP historically underwent palatalisation in onset consonant clusters containing initial obstruents $/ \mathrm{k}, \mathrm{g}, \mathrm{p}, \mathrm{b}, \mathrm{f} /$, where a number of variants of /1/ are possible (see Table 1 ).

3 Note that Saint-Symphorien-sur-Coise was also a commune explored for the ALF; see therein data point 818 (male, born 1850s, interviewed 1901). 
Table 1: Possible forms for /C/ + / / clusters (adapted from Stich 1998: 47-50).

\begin{tabular}{|c|c|}
\hline Type of cluster & Possible variants \\
\hline$/ \mathrm{kl} /$ & $[\mathrm{kl}],[\mathrm{k} K],[\mathrm{t}]],[\kappa],[j],[c ̧]],[c ̧ \kappa],[c ̧],[\mathrm{tl}],[\theta]$ \\
\hline$/ \mathrm{gl} /$ & [gl], [gא], [К], [j], [ð] \\
\hline$/ \mathrm{pl} /$ & {$[p l],[p \kappa],[p j],[p \theta],[p f]$} \\
\hline$/ \mathrm{bl} /$ & [bl], [bK], [bj], [bð], [bv] \\
\hline$/ \mathrm{fl} /$ & {$[f l],[f \kappa],[c ̧ l],[c ̧ \kappa],[c ̧],[\theta]$} \\
\hline
\end{tabular}

As shown in Table 1, all five possible onset clusters can show /1/-palatalisation in FP. In addition to the reflexes $[1],[K]$ and $[j]$, we also find a number of fricative articulations, which are secondary evolutions following palatalisation. While Jänicke (1997) suggests that this feature emerged in Romance in the fifteenth century, the first written attestations in FP appear during the seventeenth century, and in the Lyonnais area only in the first half of the eighteenth century. Not all dialects of FP have /1/-palatalisation in all five onset clusters. Historically, the evolution began with $/ \mathrm{kl}, \mathrm{gl} /$, and some dialects never extended palatalisation to /pl, bl, fl/ (see Müller 2011: Ch3 for discussion).

Table 2 provides examples of /1/-palatalisation in the Lyonnais varieties of FP, and compares them with SF. As we can see, the Classical Latin form GLACIËM is realised as ['gjasi] synchronically in these varieties, but [glas] in $\mathrm{SF}$. As Table 2 illustrates, according to the ALLy, /1/ is palatalised to [j] when following a velar consonant, but not a labial; /1/-palatalisation is therefore only contextually conditioned by initial / $\mathrm{k}, \mathrm{g} /$ in les monts du Lyonnais, unlike in some other regions of the FP-speaking zone, such as the Val de Bagne (Switzerland), where palatalisation is extended to the labial sets (Kasstan 2015a). Therefore, there are internal- and external-linguistic

Table 2: /1/-palatalisation in Lyonnais FP (after the ALLy).

\begin{tabular}{|c|c|c|c|}
\hline Etymon & FP & SF & English Gloss \\
\hline CLĀRAM & [kјวь] & {$[\mathrm{kl \varepsilon R}]$} & ‘clear’ \\
\hline GLACIĒM & ['gjasi] & [glas] & 'mirror' \\
\hline PLĒNUM & [plẽ $]$ & {$[p l \tilde{\varepsilon}]$} & ‘full’ \\
\hline *BLĀDU & [blo] & [ble] & 'wheat' \\
\hline FLŌREM & [flø] & [flœR] & 'flower' \\
\hline
\end{tabular}


constraints operating on /1/-palatalisation: we refer to this sociolinguistic variable as (1).

\section{Methodology}

Fieldwork was conducted in 2012 in les monts du Lyonnais. Speech samples were collected from three categories of speakers with different acquisition routes: 16 native speakers were sampled who had acquired FP through intergenerational transmission (see Section 5.1, below); two speakers were sampled who had acquired FP later in life, but still in the family setting (Section 5.2), and three new speakers were included who were all universityeducated, and had acquired FP either in the context of voluntary evening classes provided by native speakers, or through the use of some available pedagogy (e.g. Martin 2006) (Section 5.3). Owing to the well-known issues relating to representative sampling and data collection in endangered-language communities (e.g. Jones 2001), judgment sampling was employed. We note here the imbalance across the speaker groups, which is reflected in the data to be discussed below (see Section 6). Any later conclusions derived from these data must therefore be drawn with care. Participants' demographic information is given in Appendix A.

To elicit both monitored and unmonitored speech, semi-structured sociolinguistic interviews were conducted with speakers individually and in L1/L2 mixed groups (for details, see Table 3, where each row represents one interview; dashes mean no speakers present). For the individual interviews, a wordlist translation task was included to elicit more monitored speech. The items included in the list (see Appendix B) contain examples of OL clusters in wordinitial, medial and final position. Although /1/-palatalisation is only anticipated in syllable onset, additional contexts were included to establish whether palatalisation has generalised to other contexts. As far as possible, both styles are analysed below. However, it was not possible to elicit both styles from every participant in the study, owing to the frailty of many of the participants, and so

Table 3: Group-interview pairings.

\begin{tabular}{lrr}
\hline Native & Late & New \\
\hline A06-09, P18-03, R12-17 & C12-01, L16-18 & A18-23 \\
P18-03 & - & A18-23 \\
J10-15, J10-16 & - & A18-23 \\
\hline
\end{tabular}


the data are fragmentary. This is, however, to be expected of research undertaken on severely endangered languages (e.g. Rau 2013).

Following Foulkes et al. (2010: 720), the coding of variants for the study was done primarily on an auditory basis. Where doubt arose between two possible forms, the coding of each variant in the corpus was backed up by spectrogram readings in Praat (version 5.3.17, Boersma and Weenink 2012). Spectrogram settings were kept to a frequency view range of $6000 \mathrm{~Hz}$, with a dynamic range of $50.0 \mathrm{~dB}$, which was deemed acceptable for the measurement of F1/F2/F3.

\section{1 "Native" speaker category}

"Native" speakers are defined here as having acquired FP from birth through either the home or community environment. These speakers correspond to Bert's “traditional speakers” (2009: 30) and Dorian's “oldest fluent speakers” (1981: 116). The distinction between "home" and "community" is made here due to the fact that speakers often downplayed the presence of FP in the family home, and, during interviews, frequently claimed that they acquired FP from other members of the community, such as a grandparent. In fact, many of the Lyonnais native speakers sampled claimed that their parents still spoke FP to each other in the home, but not to the participants as children. This suggests that the cut-off point for intergenerational transmission was already well advanced for these speakers as young children. In this respect, they can also be compared with Bert's "aged late speakers" whose linguistic practices are "almost similar to those of traditional speakers, and, like traditional speakers, they do not suffer from any particular linguistic insecurity" (2009: 31).

\section{2 "Late" speaker category}

"Late” speakers correspond to Bert's “young late speakers” (2009: 31), and Dorian's “younger fluent speakers” (1981: 116), who were born after the cut-off point for transmission, and were raised as French-speaking monolinguals. Acquisition of FP then began passively, where later in life (typically as teenagers), they began to engage in regular use of FP, often with close members of the family; these speakers are typically male. Bert describes them as speakers whose "language use evidences changes and simplifications, and words from certain semantic fields are unknown to them” (2009: 31). 


\section{3 “New speaker” category}

As outlined above, new speakers differ markedly from native/late speakers. They acquire the minority variety as an intellectual exercise, and the variants employed by these speakers can be significantly removed from traditional norms. New speakers tend to be concentrated in areas that may be very different in socioeconomic terms from the rural communities so far described. Owing to underlying sociolinguistic differences in comparison with native speakers, new speakers have even been documented elsewhere as perceiving themselves to be "socially and linguistically incompatible" (O'Rourke and Ramallo 2011: 139). Bert et al. (2009: 42) have also defined new speakers of FP as having "acquired the language on a voluntary basis, in an academic context or in adult classes, rather than within the family or village setting". Therefore, owing to the method of acquisition, there is a great deal of variation in individual speaker-proficiency.

While the three new speakers sampled in this study have different levels of proficiency, they all belong to the same FP (or "Arpitan") revitalisation movement (see Bichurina, this issue). This movement militates for the linguistic unity of FP in a region ("Arpitania") that has never known any unity, linguistic or otherwise, and, in particular, campaigns for wider literacy through the use of a proposed pan-regional standard orthographical norm, termed Reference Orthography $B$ (ORB) (Stich 2001). All three new speakers subscribe to these principles and have adopted ORB. This is important to the present study for two reasons. First, as new speakers have access to little native-speaker input, their main channel of communication is predominantly through the Internet, and orthography plays a significant role in their day-to-day production. Second, /1/-palatalisation is represented orthographically in ORB with the grapheme $<1 l>$. It is noteworthy that the "recommended pronunciation" for this $<11>$ grapheme is the palatal lateral approximant $[K]$, which the authors have chosen because they claim it to be the "prononciation majoritaire" [majority pronunciation] for the FP-speaking region (Stich 1998: 78). Therefore, the grapheme < cll > for the OL cluster [kj] in les monts $\mathrm{du}$ Lyonnais has the "recommended pronunciation" [kK], despite the fact that this is not an attested variant for the region (Kasstan 2015b).

\section{Results}

Beginning first with the native speakers, we find the anticipated pattern: palatalisation occurs in the velar + lateral sets, but not in the labial + lateral sets (see Table 4; example variants are given in Appendices B and C). No tokens were elicited that evidenced palatalisation in coda position. 
Table 4: Distribution of variants by native speakers.

\begin{tabular}{rrrrrr}
\hline & /kl/ & /gl/ & $/ \mathbf{p l} /$ & $/ \mathbf{b l} /$ & $/ \mathbf{f l} /$ \\
\hline ll] & $51 \%(45)^{\mathrm{a}}$ & $49 \%(31)$ & $99 \%(70)$ & $100 \%(86)$ & $100 \%(23)$ \\
{$[\mathrm{j}]$} & $49 \%(44)$ & $51 \%(32)$ & $1 \%(1)$ & $0 \%$ & $0 \%$ \\
\hline
\end{tabular}

${ }^{\mathrm{a}}$ Values in parentheses represent token counts.

However, it is clear from Table 4 that, within the velar clusters, there are also many [1] tokens, indicating that palatalisation is variable, while there is virtually no palatalisation in the labial clusters. By and large, then, native speakers converge on the expected pattern for (1), given the historical evidence presented in the ALF and the ALLy. Moreover, it is revealing that the fieldwork site closest to the border of the FP-speaking region has the lowest palatalisation rates (see Table 5, which compares St-Martin-en-Haut and St-Symphorien-sur-Coise).

Table 5: Native speaker ///-palatalisation frequencies by fieldwork site.

\begin{tabular}{lrr}
\hline & $/ \mathbf{k l} /$ & $/ \mathbf{g l} /$ \\
\hline St-Martin-en-Haut & & \\
{$[\mathrm{l}]$} & $44 \%(19)$ & $36 \%(13)$ \\
[j] & $56 \%(24)$ & $64 \%(23)$ \\
St-Symphorien-sur-Coise & & \\
[l] & $84 \%(16)$ & $96 \%(26)$ \\
[j] & $16 \%(3)$ & $4 \%(1)$ \\
\hline
\end{tabular}

There were far fewer late speakers sampled, with just 48 tokens elicited (see Table 6). Despite the poverty of data, it is noteworthy that patterns of palatalisation are consistent with those of the native speaker category.

Table 6: Distribution of variants by late speakers.

\begin{tabular}{rrrrrr}
\hline & /kl/ & /gl/ & /pl/ & /bl/ & /fl/ \\
\hline$[\mathbf{l}]$ & $18 \%(2)$ & $20 \%(1)$ & $100 \%(18)$ & $100 \%(13)$ & $100 \%(1)$ \\
{$[\mathrm{j}]$} & $82 \%(9)$ & $80 \%(4)$ & $0 \%$ & $0 \%$ & $0 \%$ \\
\hline
\end{tabular}

The late speaker data also point towards the acquisition of velar + lateral palatalisation, and no instances of palatalisation were found in the labial sets.

The new speakers too show evidence of having acquired the velar + lateral pattern, but, crucially, they also differ from the other speaker-types here, in that 
both [j] and [i] are produced in the $/ \mathrm{kl}, \mathrm{gl} /$ sets (Table 7 ). We therefore find an additional variant, unattested in the literature for this part of the FP-speaking zone. Moreover, five tokens evidence that /1/-palatalisation is extended to the / bl/ set, too.

Table 7: Distribution of variants by new speakers.

\begin{tabular}{lrrrrr}
\hline & $/ \mathbf{k l} /$ & $/ \mathbf{g l}$ & $/ \mathbf{p l}$ & $/ \mathbf{b l}$ & $/ \mathbf{f l} /$ \\
\hline$[\mathbf{l}]$ & $33 \%(6)$ & $44 \%(4)$ & $100 \%(24)$ & $85 \%(28)$ & $100 \%(1)$ \\
{$\left[\mathbf{l}^{\prime}\right]$} & $33 \%(6)$ & $12 \%(1)$ & $0 \%$ & $6 \%(2)$ & $0 \%$ \\
[j] & $33 \%(6)$ & $44 \%(4)$ & $0 \%$ & $9 \%(3)$ & $0 \%$ \\
\hline
\end{tabular}

We therefore observe in our data a number of interesting trends. The native and late speakers both fall in line with expectations: palatalisation takes place in the velar sets, where the predicted variant [j] arises. However, even among the most fluent speakers, /1/-palatalisation is far from categorical: in all, only half the velar cluster tokens exhibit palatalisation. Conversely, while the new speakers demonstrate similar levels of variability, there is a greater range of palatalised variants. In addition to [j], we also observe [1] in the data: a variant not present in either the ALF or the ALLy for this area. In addition, new speakers are extending palatalisation from the velar sets to the labial sets.

There is no gender effect in the data. Despite the fact that there is a gender imbalance in the sample (see Appendix A), and a disproportionate number of tokens were provided by male speakers $(\mathrm{N}=136$, female tokens $\mathrm{N}=17)$, Table 8 shows that the velar + lateral pattern is evident in the speech of both groups, with similar palatalisation rates at $\sim 50 \%$. A Fischer's exact 2-tail test reveals the difference between males and females to be statistically non-significant, $p=0.69$.

Table 8: Native speaker ///-palatalisation frequencies by gender.

\begin{tabular}{lrr}
\hline & Females & Males \\
\hline$[\mathrm{l}]$ & $41 \%(7)$ & $51 \%(69)$ \\
{$[\mathrm{j}]$} & $59 \%(10)$ & $49 \%(66)$ \\
\hline
\end{tabular}

When we compare speech style across speaker types, we find that /1/-palatalisation is much more likely in a more monitored speech style than in casual speech 
(Tables 9 and 10). A Fischer's exact 2-tail test reveals this to be highly significant at $p=<0.0001$ among the native speakers. ${ }^{4}$

Table 9: Native speaker ///-palatalisation frequencies by style.

\begin{tabular}{lrr}
\hline & $/ \mathbf{k l} /$ & $/ \mathbf{g l} /$ \\
\hline Wordlist & & \\
{$[\mathrm{l}]$} & $41 \%(28)$ & $43 \%(24)$ \\
{$[j]$} & $59 \%(41)$ & $57 \%(32)$ \\
Casual & & \\
{$[\mathrm{l}]$} & $94 \%(17)$ & $100 \%(7)$ \\
{$[j]$} & $6 \%(1)$ & $0 \%$ \\
\hline
\end{tabular}

Table 10: New speaker ///-palatalisation frequencies by style.

\begin{tabular}{|c|c|c|c|}
\hline & /kl/ & $/ g l /$ & /bl/ \\
\hline \multicolumn{4}{|c|}{ Wordlist } \\
\hline$[l]$ & $21 \%(3)$ & $17 \%$ (1) & $40 \%(2)$ \\
\hline$\left[l^{i}\right]$ & $43 \%(6)$ & $17 \%$ & $40 \%(2)$ \\
\hline [j] & $36 \%(5)$ & $67 \%(4)$ & $60 \%$ (3) \\
\hline \multicolumn{4}{|c|}{ Casual } \\
\hline [l] & $100 \%$ (1) & $100 \%$ (3) & $100 \%(10)$ \\
\hline
\end{tabular}

This pattern is clearest amongst the new speakers, who exhibit zero palatalisation in casual speech. What is perhaps more interesting, however, is that the new speakers extend palatalisation to the /bl/ cluster. This can be contrasted with the native speaker and late speaker data where this isn't the case.

In summary, when speech is more monitored, there is an increased rate of /1/-palatalisation than in unmonitored speech. It is, however, in the new-speaker category where we find a more diverse range of palatalised variants for $/ 1 /$. Moreover, if the new speaker data are shown by individual speaker, we see that the [1] $\left.{ }^{i}\right]$ variant is only produced by one speaker (see Table 11); we discuss this point below.

4 Owing to the very small token numbers in the late/new speaker data, it would not be fruitful to run these data through the same battery of tests. 
Table 11: New speaker ///-palatalisation frequencies by participant.

\begin{tabular}{lrrr}
\hline Variant & \multicolumn{3}{c}{ Research participant } \\
\hline & $A 18-23$ & $S 07-17$ & $D 20-25$ \\
{$[$ l] } & $74 \%(40)$ & $67 \%(8)$ & $79 \%(15)$ \\
{$[$ li] } & $17 \%(9)$ & $0 \%$ & $0 \%$ \\
[j] & $9 \%(5)$ & $33 \%(4)^{\mathrm{a}}$ & $21 \%(4)$ \\
\hline
\end{tabular}

${ }^{\mathrm{a}}$ Two of these tokens were produced in the /bl/ set.

\section{Discussion}

The evidence from the ALF and ALLy suggests that our informants should only palatalise /1/ in the velar sets, where [j] was expected. However, new speakers extended palatalisation to some labial clusters. In addition to [j], [i $\left.{ }^{i}\right]$ also emerged as a possible (l) variant. Furthermore, among the native speakers there is significant intraspeaker variation in the velar clusters. In addition, late and new speakers were also producing [1] in the velar clusters. We will first discuss the behaviour of the native and late speakers with respect to the dialectal information reported from both the ALF and the ALLy, and then turn to the new speakers.

The speakers that provided the information for the ALF were born in the 1850s-1870s, with an average age of 40 (Gillierron and Edmont 1902-1910), whereas the informants of the ALLy were born in the 1890s-1900s with an average age of 70 (Gardette 1950-1956, Fascicule 1: 53). Our native speakers were born during the interwar period. Each set of informants, for the ALF, the ALLy, and our study, thus represent different generations. That said, we must remain mindful of the methods employed in the ALF and the ALLy as compared to the present study (i.e. regional dialectology in the former, and variationist sociolinguistics in the latter). While the / $\mathrm{kl}, \mathrm{gl} /$ clusters are consistently reported as [kj, gj] in the ALF and ALLy groups, given the methods employed at the time, we cannot be confident that these variants are not examples of what can be termed Demonstrationsmundart [demonstration dialect], i.e. hypercorrected forms or authentication in action. We can however be confident that our speakers overwhelmingly realised [kl, gl] in spontaneous speech, whereas in the wordlist task, [kl, gl] had a prevalence of $\sim 40 \%$. It is also clear that $/ 1 /$ palatalisation in the velar sets was less likely in Saint-Symphorien-sur-Coise than any other area explored in the Lyon area. There are therefore two discrepancies with the historical data that require explanation: (i) the variability in palatalisation in the velar sets, and (ii) lowest rates of palatalisation in the 
western-most fieldwork site. First, one possible explanation for $\sim 50 \%$ palatalisation rates in the velar clusters is increased contact with SF, which did not develop /1/-palatalisation in OL onset clusters, despite its short appearance as an upper-class fad in the sixteenth century. The argument for contact-induced change is augmented by the fact that data from the western-most site show the lowest palatalisation rates. While data from the ALF and ALLy evidence that palatalisation in OL clusters was a feature of the Oil dialects of the southern Saône-et-Loire department, the quantitative data here indicates that phonological levelling is taking place in the direction of SF. This is consistent with the language death literature, and such findings are now widely reported in the context of other regional languages spoken in the Hexagon (e.g. Hornsby 2006 on Picardie). An analogous change can also be found in the shift from $[\Lambda]$ to $[1]$ in the OL clusters of Saviesan FP, spoken in Valais (Switzerland), which is attested by Jeanjacquet 1931: 40) and confirmed empirically by Kasstan (2015a: Ch 5).

We turn next to the new-speaker data, where the [li] variant was only found in the speech of participant A18-23, as were most of the palatalised /bl/ clusters. While S07-24 also produced two [j] tokens in the labial sets, D20-25 produced no palatal variants. Regarding the emergence of $\left[\mathrm{l}^{\mathrm{i}}\right]$ - a variant unattested in the literature for this part of the FP-speaking region - we advance two possible explanations. First, given that A18-23 was raised as a monolingual French speaker, acquiring FP in adulthood, we could posit that this variant represents an "interdialectal" (Trudgill 1986: 60) or "intermediate form" (Hornsby 2009: 172): a compromise between FP and French. The emergence of such variants in endangered-language contexts are not new and might provide a means for speakers to “distanciate” (Thiers 1993: 265) themselves from the dominant language. There are analogous findings elsewhere in the literature. Christen (1988) found that speakers who were less fluent in their dialect would produce larger amounts of the most saliently dialectal forms in wordlists than in spontaneous speech. She interprets this higher production rate in word-elicitation tasks as speakers choosing to distanciate themselves from the regional standard variety. It is possible that such a behaviour is especially favoured when the dialect is closely related to the standard (or dominant) language, as in the case of the Western Swiss German regional standard and the rural local dialect, and, in our case, of the local FP variety and SF. Alternatively, we might posit that $\mathrm{ORB}$, and membership to the new-speaker movement, is having some impact on language production. We said above that this proposed orthographical norm "recommends" $[K]$ as a pronunciation for the $<$ ll $>$ grapheme. While we are not making the claim here that $\left[\mathrm{l}^{\mathrm{i}}\right]$ and $[\Lambda]$ are the same phone, it is noteworthy that these speakers are much more likely to produce FP in writing than in speech. If we adopt the argument that ORB is indeed having some impact on language production, then we can also lean on the evidence coming from the new-speaker sample in 
general that palatalisation is extended to the labial sets, which also bear the grapheme $<$ ll $>$ in ORB (i.e. $<$ bll $>$, $<$ pll $>$, $<$ fll $>$ ). We did note however that such forms only emerged in the most careful speech style (and not in L1/L2 group interactions). We can therefore further suggest that (l) is imbued with some social meaning for our new speakers: it is produced to convey (or index, following Silverstein 2003) affiliation with Arpitan and Arpitania, rather than FP locally defined. We must hedge these observations with the caveat that the token count among these individuals remains very small. This is not to say, though, that low token counts in a small sample are not meaningful. Trudgill in his discussion on socalled "vestigial" or "embryonic forms" has warned that "we should not [...] ignore features that [...] occur only in a small number of contexts [...] or [...] in the speech of a small number of people" (1999: 319). Trudgill's discussion focuses on a small portion (<5\%) of his 1971 sample, and their production of the labio-dental approximant [u]. Trudgill initially dismisses this finding as an "idiosyncratic speech impediment" (1999: 319). However, when he returned for a follow-up study in 1983 the number of participants in his study who employed [v] had "increased significantly" (1999: 319). Trudgill concludes from this that such variants might well represent "the seeds of later change" (1999: 320). In Trudgill's terms then, our suspect Arpitan forms might better fit the description of embryonic variants, that "may represent the very earliest stages of linguistic change in progress" (1999: 320). Although they are rarely used in our sample, they do appear to have taken hold amongst a particular group to convey social meaning. Evidence from the literature abounds that suggests such environments to be hospitable for linguistic change to occur over time.

\section{Conclusion}

We have explored three groups of FP speakers with the aim of understanding the use of (1): the palatalisation of /1/ in OL onset clusters. Our speakers included a group of older speakers, who had acquired the language at home, a group of middle-aged speakers, who acquired the language after childhood, but still in an immersion setting, and finally a group of new speakers, who chose to learn FP in an educational setting.

First of all, we found a discrepancy between the historical data reported in the ALF and the ALLy for the rate of /l/-palatalisation in the velar sets. Whereas [kj, gj] were traditional variants for these clusters up until the 1950s, today's older group of speakers no longer uses these forms in casual speech, where instead the SF forms $[\mathrm{kl}, \mathrm{gl}]$ appear to be winning out. Secondly, we observed a large difference in the use of the palatalised variant between the wordlist translation task and spontaneous 
speech for all speaker groups. Given the overwhelming dominance of SF in the life of even the oldest speaker group, born during the interwar period, we attribute the use of [1] in the velar sets to contact-induced change. While (l) has for some time been the subject of metalinguistic commentary, this feature of FP appears to be undergoing phonological levelling. ${ }^{5}$

Thirdly, we noted the use of the variant [ $\left.\mathrm{i}^{\mathrm{j}}\right]$ by one new speaker. This variant was not observed in any other speaker, and was not reported in the ALF and the ALLy. There was additionally some small evidence to suggest that the new speakers too generally extended /1/-palatalisation to the labial sets, which is not a feature of Lyonnais FP. We have speculated that these observations might represent further evidence for the social-indexical salience of sub-phonemic variation in laterals, as documented elsewhere (Section 2).

In conclusion, although we make use of limited data, our study has contributed to the understanding of socio-indexical usage of one phonetic cue in the context of both language death and revitalisation. We hope to continue to deepen this understanding in the future by examining the interplay between intra-linguistic evolution, societal contexts, and socio-phonetic uses by extending the questions raised in the present study to further regional minority language contexts in France as well as other European countries.

Acknowledgements: The authors wish to thank Naomi Nagy and two anonymous reviewers for helpful comments on earlier versions of this article.

\section{References}

Bert, Michel. 2009. Typologie des locuteurs de langues menacées d'extinction: Le cas du francoprovençal et de l'occitan dans la région du Pilat (France). In Claudine Fréchet (ed.), Langues et cultures de France et d'ailleurs, 25-38. Lyon: Presses universitaires de Lyon.

Bert, Michel, James Costa \& Jean-Baptiste Martin. 2009. Étude FORA : Francoprovençal et occitan en Rhône-Alpes. Étude Pilotée par l'Institut Pierre Gardette. Lyon: Université catholique de Lyon.

Boersma, Paul \& David. Weenink. 2012. Praat: Doing phonetics by computer [Computer program]. Version 5.3.17.

Campbell, Lyle \& Martha C. Muntzel. 1989. The structural consequences of language death. In Nancy C. Dorian (ed.), Investigating Obsolescence, 181-196. Cambridge: Cambridge University Press.

5 It is also possible that language-internal structural pressure may have contributed to the loss of the palatal variant since the labial clusters never underwent palatalisation in Lyonnais FP. This needs to be confirmed by further research. 
Christen, Helen. 1988. Sprachliche Variation in der deutschsprachigen Schweiz dargestellt am Beispiel der l-Vokalisierung in der Gemeinde Knutwil und in der Stadt Luzern. Stuttgart: Franz Steiner Verlag Wiesbaden GmbH.

Christen, Helen. 2001. Ein Dialektmarker auf Erfolgskurs: Die /L/-Vokalisierung in der deutschsprachigen Schweiz. Zeitschrift für Dialektologie und Linguistik 68(1). 16-26.

Dorian, Nancy C. 1981. Language death: The life cycle of a Scottish Gaelic dialect. Philadelphia: University of Pennsylvania Press.

Duraffour, Antoine. 1932. Phénomènes généraux d'évolution phonétique dans les dialectes francoprovençaux étudie d'après le parler de la commune de Vaux (Ain). Revue de Linguistique Romane 8. 1-280.

Foulkes, Paul, James. M. Scobbie \& Dominic Watt. 2010. Sociophonetics. In William J. Hardcastle, John Laver \& Fiona E. Gibbon (eds.), The handbook of phonetic sciences, 703-754. Oxford: Wiley-Blackwell.

Gardette, Pierre. 1950-1956. Atlas linguistique et ethnographique du Lyonnais. Paris: Éditions du C.N.R.S.

Gick, Bryan. 2002. The American intrusive I. American Speech 77(2). 167-183.

Gilliéron, Jules \& Edmond Edmont. 1902-1910. Atlas Linguistique de la France. Paris: Champion.

Hornsby, David. 2006. Redefining Regional French: Koinéization and Dialect Levelling in Northern France. Oxford: Legenda.

Hornsby, David. 2009. Dedialectalization in France: Convergence and divergence. International Journal of the Sociology of Language 196-197. 157-180.

Horvath, Barbara M. \& Ronald J. Horvath. 2002. The geolinguistics of /// vocalization in Australia and New Zealand. Journal of Sociolinguistics 6(3). 319-346.

Jänicke, Otto. 1997. Studien zur Palatalisierung des Nexus Kons. + [l] in der Galloromania. Hamburg: Kovač.

Jeanjacquet, Jules. 1931. Les patois valaisan: Caractères généraux et particularités. Revue de Linguistique Romane 7. 22-51.

Jones, Mari. C. 1995. At what price language maintenance? Standardization in Modern Breton. French Studies XLIX(3). 428-436.

Jones, Mari. C. 1998. Language Obsolescence and Revitalization: Linguistic Change in Two Sociolinguistically Contrasting Welsh Communities. Oxford: Clarendon Press.

Jones, Mari C. 2001. Jersey Norman French: A linguistic study of an obsolescence dialect. Oxford: Blackwell.

Kasstan, Jonathan R. 2015a. Variation and change in Francoprovençal: A study of an emerging linguistic norm. Canterbury: University of Kent dissertation.

Kasstan, Jonathan R. 2015b. Illustrations of the IPA: Lyonnais (Francoprovençal). Journal of the International Phonetic Association 45(3). 340-355.

Kasstan, Jonathan R. 2017. New speakers: Challenges and opportunities for variationist sociolinguistics. Language and Linguistics Compass 11(8). e12249.

Leeman, Adrian, Marie-José Kolly, Iwar Welen, David Britain \& Dieter Studer-Joho. 2014. The diffusion of ///-vocalisation in Swiss German. Language Variation and Change 26(2). 191-218.

Martin, Jean-Baptiste. 2006. Le Lyonnais de Poche. Chennevières-sur-Marne: Assimil.

Müller, Daniela. 2011. Developments of the lateral in Occitan dialects and their Romance and cross-linguistic context. Universitat de Tolosa 2 - Lo Miralh \& Ruprecht-Karls-Universität Heidelberg dissertation. 
O’Rourke, Bernadette, Joan Pujolar \& Fernando Ramallo. 2015. New speakers of minority languages: The challenging opportunity - Foreword. International Journal of the Sociology of Language 231. 1-20.

O’Rourke, Bernadette \& Fernando Ramallo. 2011. The native-non-native dichotomy in minority language contexts: Comparisons between Irish and Galician. Language Problems \& Language Planning 35(2). 139-159.

Rau, Victoria D. 2013. Cross-cultural issues in studying endangered indigenous languages. In Christine Mallinson, Becky Childs \& Gerard Van Herk (eds.), Data collection in sociolinguistics: Methods and applications, 101-104. London: Routledge.

Silverstein, Michael. 2003. Indexical order and the dialectics of social life. Language and Communication 23(3-4). 193-229.

Simonet, Miquel. 2010. Dark and clear laterals in Catalan and Spanish: Interaction of phonetic categories in early bilinguals. Journal of Phonetics 38. 663-678.

Stich, Dominique. 1998. Le Francoprovençal : Langue méconnue. Paris: L’Harmattan.

Stich, Dominique. 2001. Francoprovençal: Proposition d'une orthographe supra-dialectal standardisée. Université Sorbonne - Paris V dissertation.

Straka, Georges. 1942. Notes sur la vocalisation de l’l. Bulletin Linguistique 10. 1-34.

Thiers, Ghajacumu. 1993. Language contact and Corsican polynomia. In Rebecca Posner \& John N. Green (eds.), Trends in romance linguistics and philology, vol V, 253-270. Berlin: Mouton de Gruyter.

Trudgill, Peter. 1986. Dialects in contact. Oxford: Blackwell.

Trudgill, Peter. 1999. New-dialect formation and dedialectalisation: Embryonic and vestigial variants. Journal of English Linguistics 27(4). 319-327.

Tuaillon, Gaston \& Jean-Baptiste Martin. 1971-1981. Atlas linguistique et ethnographique du Jura et des Alpes du Nord. Paris: Éditions du C.N.R.S.

\section{Appendix}

\section{A Participant demographics}

\begin{tabular}{lllrl}
\hline$\#$ & Speaker type & Sex & Age group & Fieldwork site \\
\hline P18-03 & Native & M & $70-80+$ & St-Martin-en-Haut \\
C06-04 & Native & M & $70-80+$ & St-Martin-en-Haut \\
M06-05 & Native & F & $70-80+$ & St-Martin-en-Haut \\
J18-06 & Native & F & $70-80+$ & St-Martin-en-Haut \\
J02-07 & Native & M & $70-80+$ & Rontalon \\
G07-02 & Native & M & $70-80+$ & Rontalon \\
C03-08 & Native & M & $70-80+$ & Rontalon \\
A06-09 & Native & M & $70-80+$ & St-Symphorien-sur-Coise \\
C06-10 & Native & F & $70-80+$ & St-Symphorien-sur-Coise \\
\hline
\end{tabular}

(continued) 
(continued)

\begin{tabular}{lllrl}
\hline$\#$ & Speaker type & Sex & Age group & Fieldwork site \\
\hline N22-11 & Native & M & $70-80+$ & St-Martin-en-Haut \\
022-12 & Native & F & $70-80+$ & St-Martin-en-Haut \\
M03-13 & Native & M & $70-80+$ & St-Symphorien-Sur-Coise \\
M03-14 & Native & F & $70-80+$ & St-Symphorien-sur-Coise \\
J10-15 & Native & M & $70-80+$ & St-Martin-en-Haut \\
J10-16 & Native & F & $70-80+$ & St-Martin-en-Haut \\
R12-17 & Native & M & $70-80+$ & Yzeron \\
C12-01 & Late & M & $45-70$ & Yzeron \\
L16-18 & Late & M & $45-70$ & Mornant \\
A18-23 & New & M & $20-45$ & Lyon \\
S07-24 & New & M & $20-45$ & Lyon \\
D20-25 & New & M & $20-45$ & Lyon \\
\hline
\end{tabular}

\section{B Wordlist translation task - items for (l)}

\begin{tabular}{ll}
\hline SF & English gloss \\
\hline pleurer (inf.) & 'cry' (inf.) \\
pleurez (2nd p. pl.) & 'cry' (2nd p. pl.) \\
recyclage & 'recycling' \\
bible & 'bible' \\
(être) souple & '(to be) flexible' \\
cloches & 'bells' \\
glas & 'tolling bell' \\
plus claire & 'clear' \\
flamme & 'flame' \\
aveugle & 'blind person' \\
tables & 'tables' \\
portable & 'portable' \\
\hline
\end{tabular}




\section{Example lexical items from spontaneous speech}

\begin{tabular}{|c|c|c|}
\hline FP & SF & English Gloss \\
\hline [кјјь $]$ & clair & ‘clear’ \\
\hline ['kjगయi] & cloche & ‘bell’ \\
\hline [kj’] & clef & ‘key’ \\
\hline ['gjasi] & glace & ‘mirror' \\
\hline [gjग] & glas & 'tolling bell' \\
\hline [pl $\tilde{\varepsilon}]$ & plein & 'full' \\
\hline ['plezi] & plaisir & 'pleasure' \\
\hline [ply] & plus & 'more' \\
\hline [blo] & blé & 'wheat' \\
\hline ['blesi] & blessé & ‘injured’ \\
\hline [blã] & blanc & 'white' \\
\hline [flø] & fleur & ‘flower’ \\
\hline ['floma] & flamme & 'flame’' \\
\hline [flã] & flan & 'pudding' \\
\hline
\end{tabular}

